\title{
BEST PRACTICE PENGEMBANGAN MEDIA PEMBELAJARAN PPKn BERBASIS ANDROID DI PERGURUAN TINGGI
}

\author{
Nurul Zuriah ${ }^{1}$, Naufal M Kautsar ${ }^{2}$ \\ ${ }^{1,2}$ Univeristas Muhammadiyah Malang, Indonesia \\ 'Email: zuriahnurulzuriah@yahoo.co.id
}

\begin{abstract}
ABSTRAK
Artikel ini menjelaskan Best Practice Pengembangan Media Pembelajaran PPKn Berbasis Android di Perguruan Tinggi. Subyek penelitiannya adalah mahasiswa angkatan 2017/2018 Prodi PPKn Universitas Muhammadiyah Malang pada semester pertama yang menempuh matakuliah Media Pembelajaran PPKn. Salah satu permasalahan yang muncul adalah kurang tersedianya media belajar yang mampu menarik minat belajar siswa. Berangkat dari masalah tersebut, pengembangan media belajar berbasis aplikasi android dapat menjadi salah satu pilihan inovasi dan solusi terbaik dalam pengembangan media dan sumber pembelajaran ke depan. Penelitian dilakukan dengan penelitian pengembangan model ADDIE Model, yang terdiri dari lima langkah, yaitu: (1) Analisis, (2) Perancangan,(3) Pengembangan, (4) Implementasi dan (5) evaluasi. Penelitian menghasilkan sebuah produk media pembelajaran berbasis aplikasi android dalam matakuliah Pengembangan Media dan Sumber Belajar di jurusan PPKn-FKIP UMM. Salah satu modelnya adalah media BENEKO Educapp. Komponen media pembelajaran yang dikembangkan meliputi fitur video pembelajaran PPKn, fitur buku digital, fitur quis untuk latihan dan evaluasi, fitur game untuk sarana refreshing siswa ketika jenuh dalam belajar, terakhir fitur chat room untuk sarana sharing antar guru dan siswa ketika susah memahami materi yang ada. Media di desain dengan menggunakan power point kemudian di convert ke aplikasi android menggunakan aplikasi andraired, desain aplikasi android terbukti menarik sesuai karakter peserta didik.
\end{abstract}

Kata Kunci: Best Practice; Media Pembelajaran; Android;ADDIE Model; BENEKO Educapp.

\section{ABSTRACT}

This article explains the Best Practice of Developing Android-Based PPKn Learning Media in Higher Education. The research subjects were students of 2017/2018 PPKn University of Muhammadiyah Malang Study Program in the first semester who took the PPKn Learning Media course. One problem that arises is the lack of learning media that can attract student learning interest. Departing from these problems, the development of learning media based on Android applications can be one of the best innovation choices and solutions in developing media and teaching resources going forward. The research carried out with ADDIE Model development research, which consisted of five steps, namely: (1) Analysis, (2) Design, (3) Development, (4) Implementation, and (5) evaluation. The research produced an android application-based learning media product in the Media Development and Learning Resources course in the PPKn - FKIP UMM major. One model is the BENEKO Educapp media. Learning media components developed include PPKn learning video features, digital book features, quiz features for practice and evaluation, game features for students' refreshing facilities when they are bored in learning, finally the chat room features for sharing between teachers and students when it is difficult to understand existing material The media is designed by using a PowerPoint and then converted to an android application using an andraired form, the design of the android application proves to be attractive according to the character of the students.

Keywords: Best Practice; Learning Media; Android; ADDIE Model; BENEKO Educapp. 


\section{PENDAHULUAN}

Prodi dan jurusan PPKn-FKIP Universitas Muhammadiyah Malang, dalam bidangpendidikanharusmampumenghasilkan tenaga kependidikan yang handal dan profesional. Peningkatan kualitas lulusan perguruan tinggi dilakukan melalui kegiatan pembelajaran yang berkualitas. Belajar di perguruan tinggi yang merupakan pilihan strategis untuk mencapai tujuan individual yang berkompeten, ternyata masih jauh dari harapan.(Egerton, 2002) Selama ini pembelajaran di perguruan tinggi masih cukup banyak yang bersifat meneruskan informasi dari dosen kepada mahasiswa. Pembelajaran hendaknya memfokuskan pada proses mendidik dan tidak sekedar mentransfer pengetahuan begitu saja (P. Setyosari, 2009) (M. D. K. Degeng, Setyosari, Degeng, \& Kuswandi, 2017). Pengembangan aspek-aspek seperti kerjasama, menghargai pendapat, mengenali diri sendiri dan orang lain dan sejenisnya perlu ditumbuhkan dalam pembelajaran. Belajar di perguruan tinggi tidak hanya dituntut mempunyai ketrampilan teknis, tetapi juga mempunyai daya dan kerangka pikir serta sikap mental, kepribadian, kearifan dan wawasan yang luas.(Oey-Gardiner et al., 2017) (I. N. S. Degeng \& Darmawan, 2017) (Midun \& Ulfa, 2017)

Pembelajaran pada abad ke-21 sebagai abad belajar, menuntut perubahan paradigma belajar. Perubahan paradigma tersebut tercermin dalam perubahan pandangan terhadap belajar dan mengajar yang lebih menekankan pada dimensi sosial dan konstruktivistik. (Farisi, 2011) (Sari, 2016). Konsep-konsep belajar saat ini yang diperoleh berdasarkan penelitianpenelitian sebelumnya diperlukan untuk membelajarkan pembelajar menghadapi abad belajar. Kesuksesan individu dalam dunia kerja pada abad ke-21 tidak cukup hanya berpengetahuan luas saja, tetapi juga bagaimana menyimpan pengetahuan saat ini, mengaplikasikannya untuk memecahkan masalah baru dan berfungsi sebagai anggota tim.(Farisi, 2011) (Manullang, 2013)

Pada abad ke -21 menurut Butzin penghargaan terhadap keseragaman (uniformity) dan kesesuaian (conformity) tidak adil bagi pembelajar saat ini. Pembelajar harus belajar untuk bekerja pada tim dari budaya dan latar belakang berbeda, belajar mandiri dan mengetahui bagaimana mengelola waktu, mengetahui bagaimana memecahkan masalah, bagaimana melakukan tugas ganda dan bagaimana mengakses informasi. Dengan demikian, pembelajaran bukan berpusat pada guru atau dosen, tetapi berpusat pada pembelajar atau siswa dan mahasiswa. Pembelajaran yang berpusat pada pembelajar membutuhkan dukungan berbagai media dan sumber belajar.(Butzin \& age of accountability: The project child recipe for success. Bloomington, n.d.)

Guna memenuhi tuntutan tersebut, maka setiap dosen di perguruan tinggi dalam mengampu mata kuliah, termasuk matakuliah media dan sumber belajar PPKn, sebaiknya memilih strategi pembelajaran yang tepat dengan menggunakan media dan sumber belajar yang memudahkan mahasiswa belajar. Pembelajaran diarahkan kepada pemberdayaan mahasiswa untuk memenuhi tuntutan yang semakin kompleks. Segala permasalahan yang dihadapi oleh dosen dalam mengampu matakuliah hendaknya ditemukenali, untuk selanjutnya dicarikan solusi pemecahannya melalui kegiatan penelitian. (Budiyasa, Santyasa, \& Warpala, 2013) (Arham \& Dwiningsih, 2016).

Salah satu matakuliah penting yang mengalami permasalahan adalah matakuliah pengembangan bahan ajar, media dan sumber belajar di jurusan PPKn. Matakuliah ini dikatakan penting, karena merupakan matakuliah yang memberikan pengetahuan dan ketrampilan kepada mahasiswa bagaimana merencanakan, melaksanakan dan mengembangkan bahan 
ajar, media dan sumber belajar beserta permasalahannya di lapangan. Mata kuliah ini diberikan kepada seluruh mahasiswa Strata 1 Prodi dan Jurusan PPKn (Civic Hukum)-FKIP UMM. Permasalahan yang dihadapi dalam perkuliahan mata kuliah ini adalah kurangnya inovasi dan variasi dalam pengembangan media dan sumber belajar terutama PPT for android yang menjadi tuntutan di era digital (smart phone).

Berdasarkan latar belakang masalah di atas, maka dirumuskan empat permasalahan pokok penelitian ini sebagai berikut: (1) Bagaimana langkah-langkah pengembangan bahan ajar dan media pembelajaran PPKn berbasis Android dengan ADDIE Model; (2) Bagaimana draft produk pengembangan bahan ajar dan media pembelajaran PPKn (PPT) berbasis Android di jurusan PPKn FKIP UMM; (3) Bagaimana hasil validasi pengembangan bahan ajar dan media pembelajaran PPKn (PPT) berbasisAndroid dengan ADDIE Model; (4) Bagaimana implementasi produk pengembangan bahan ajar dan media pembelajaran PPKn (PPT) berbasis Android di jurusan PPKnFKIP UMM beserta keunggulan dan kelemahannya.

Penelitian ini menggunakan pendekatan penelitian pengembangan, yaitu: suatu proses untuk mengembangkan dan memvalidasi produk-produk yang akan digunakan dalam pendidikan dan pembelajaran.(Tegeh, Jampel, \& Pudjawan, 2015b)(Tegeh, Jampel, \& Pudjawan, 2015a) Penelitian pengembangan adalah upaya untuk mengembangkan dan menghasilkan suatu produk berupa materi, media, alat dan atau strategi pembelajaran, digunakan untuk mengatasi permasalahan pembelajaran di kelas, laboratorium dan bukan untuk menguji teori. Pengertian yang hampir sama juga dikemukakan oleh Borg \& Gall Yang Menyatakan Bahwa Penelitian Pengembangan Sebagai Usaha Untuk Mengembangkan dan memvalidasi produk-produk yang akan digunakan dalam pendidikan. Seel \& Richey (Richey \& Klein, 2014)(Richey, Klein, \& Nelson, 2004) juga memberikan pengertian pengembangan sebagai proses penerjemahan spesifikasi desain ke dalam bentuk fisik. Pengembangan atau sering disebut juga sebagai penelitian pengembangan, dilakukan untuk menjembatani antara penelitian dan praktik pendidikan.(Supriyo, Degeng, Widiati, \& Ardhana, 2017)(A. S. I. W. A. I. N. S. D. P. Setyosari, 2016)

Dalam pengembangan desain pembelajaran terdapat beberapa model yang dapat digunakan, misalnya model Degeng (1990), Instructional System (Banathy, 1968), Instructional Design Process (Kemp, 1985), Instructional Development Model (AECT, 1985), Rancangan Pembelajaran (Dick \& Carey, 1990), ADDIEModel(Analyze, Design, Development, Implementation, Evaluation Model) (Anglada, 2007) dan lain-lain.(Tegeh et al., 2015b)(Saekhow, 2015) Model-model pengembangan desain pembelajaran tersebut pada intinya menggunakan pendekatan sistem dan memiliki tujuan yang sama, yaitu untuk menghasilkan produk pembelajaran yang efektif dan efisien, Andrews \& Goodson (Andrews \& Goodson, 1980) dan Tegeh (Tegeh, Jampel, \& Pudjawan, 2014) mengemukakan empat tujuan model desain pembelajaran sistematik sebagai berikut: (1) Meningkatkan belajar dan pembelajaran dengan jalan pemecahan masalah dan umpan balik karakteristik dan pendekatan sistematik; (2) Meningkatkan manajemen desain dan pengembangan pembelajaran dengan jalan memonitor dan mengontrol fungsi pendekatan sistem; (3) Meningkatkan proses evaluasi dengan jalan mendesain komponen dan rangkaian kejadian, memasukkan umpan balik dan merevisi kejadian, yang melekat dalam model desain pembelajaran sistematik; (4) Mengetes dan membangun teori belajar dan pembelajaran dengan jalan mendesain berdasarkan teori dalam model desain pembelajaran sistematik. 
Adapun langkah-langkah rancangan pembelajaran menurut ADDIE Model adalah meliputi lima tahap, yaitu : (1) analisis (analyze), (2) Perancangan (Design) (3) Pengembangan (Development) dan (4) Implementasi (implementation) dan (5) Evaluasi (evaluation) (Mullins, 2014)(Purbasari, Kahfi, \& Yunus, 2013a) (Khadimally, 2015).

Penggunaan ADDIE Model dalam pengembangan desain pembelajaran di dasarkan pada beberapa argumen. (Schott \& Seel, 2015)(Purbasari, Kahfi, \& Yunus, 2013b).Argumentersebutadalahsebagaimana berikut; (1) Materi Pengembangan Media Pembelajaran, bahan ajar dan sumber belajar PPKn, merupakan materi yang penyajiannya memerlukan urutan-urutan tertentu secara sistematis. Sifat-sifat materi seperti ini sangat sesuai untuk dikembangkan dengan ADDIE Model; (2) Pengembangan media dan bahan ajar dengan model ini, merupakan model pengembangan yang belum banyak digunakan di Prodi PPKn-FKIP UMM. Dengan menggunakan model ini diharapkan dapat menambah pengetahuan dan ketrampilan dosen di lingkungan Prodi PPKn-FKIP UMM untuk mengembangkan bahan ajar dan media pembelajaran atau paket pembelajaran dengan berbagai model sesuai dengan karakteristik materi kuliah dan kebutuhan mahasiswa; (3) Teori pembelajaran yang mendasari ADDIE Model adalah teori pembelajaran preskriptif. Degeng (2001) mengemukakan bahwa teori pembelajaran preskriptif berupaya menpreskripsikan metode pembelajaran yang optimal untuk mencapai hasil pembelajaran yang diinginkan. Teori ini berurusan dengan penetapan metode pembelajaran setelah dua variabel lainnya, kondisi dan hasil pembelajaran diketahui. Metode pembelajaran apa pun yang ditetapkan haruslah yang paling baik (optimal) untuk mencapai hasil yang diinginkan; (4) Model ini telah memenuhi empat karakteristik yang harus dimiliki dalam pengembangan pembelajaran, yaitu: (a) mengacu pada tujuan, (b) terdapat keserasian dengan tujuan, (c) sistematik dan (d) berpedoman pada evaluasi (Tegeh et al., 2015b) (Ronald, 1987) (Miarso, 2007); (5) Model ini menggunakan pendekatan sistem dengan langkah-langkah pengembangan yang teratur dan sistematis serta dapat digunakan untuk merancang pembelajaran secara klasikal maupun individual; (6) Model ini dapat digunakan untuk pengembangan bahan pembelajaran pada ranah informasi verbal, ketrampilan intelektual, ketrampilan psikomotor dan sikap, sehingga dipandang sangat sesuai untuk pengembangan bahan ajar media dan sumber belajar di jurusan PPKn-FKIP Universitas Muhammadiyah Malang.

Android merupakan salah satu sistem operasi yang paling digemari atau digunakan oleh kebanyakan smartphone saat ini selain iOS (milik Apple. Inc). Android merupakan suatu software (perangkat lunak) yang digunakan pada mobile device (perangkat berjalan) yang meliputi sistem operasi, middleware dan aplikasi inti. Sistem operasi tersebut dapat diilustrasikan sebagai jembatan antara piranti (device) dan penggunanya, sehingga pengguna dapat berinteraksi dengan devicenya dan menjalankan aplikasi-aplikasi yang tersedia pada device (Herawati, Siroj, \& Basir, 2010)(Kurniawati, Akbar, \& Misri, 2015) (Zuriah \& Kautsar, n.d.-a). Referensi lain ditemukan bahwa "Android merupakan sistem operasi berbasis Linux yang khusus untuk perangkat bergerak seperti smartphone atau tablet" (Zuriah \& Kautsar, n.d.-a)(Kowi \& Widyanigsih, 2018).

Hasil penelitian dari Kautsar dalam skripsinya yang berjudul "Model Pengembangan Media Pembelajaran PPKn Berbasis Android di SMPN 25 Malang" menyatakan bahwa: Pendidikan Kewarganegaraan atau sering disebut PKn merupakan salah satu mata pelajaran di SMP dan SMA yang memberikan pengajaran 
tentang bagaimana menjadi warga negara yang baik. Mata pelajaran PPKn seakan akan hilang maknanya tatkala banyak dari siswa yang tidak menyukai mata pelajaran tersebut. Salah satu permasalahannya adalah kurang tersedianya media belajar yang mampu menarik minat belajar peserta didik. Sementara di sisi lain, kebutuhan akan keterjangkauan dan kemudahan akses kehidupan semakin meningkat salah satunya melalui penggunaan aplikasi android. Berangkat dari masalah tersebut, pengembangan media belajar berbasis aplikasi android dapat menjadi salah satu pilihan solusi terbaik. Disamping penggunaan yang lebih efisien, dengan media belajar berbasis aplikasi android akan semakin meningkatkan kemudahan akses belajar bagi peserta didik. Maka dari itu, BENEKO EducApp dikembangkan sebagai salah satu media pembelajaran berbasis android untuk menjadi pilihan solusi permasalahan di atas. Aplikasi ini berisi tentang kumpulan materi yang disesuaikan dengan mata pelajaran dan kurikulum yang berlaku. Selain itu, terdapat pula menu kuis untuk menguji kemampuan peserta didik dan game sebagai sarana refreshing. Untuk semakin meningkatkan keterjangkauan, maka disediakan pula aplikasi chatting yang dapat diakses oleh guru dan peserta didik. Dengan demikian diharapkan BENEKO EducApp dapat menjadi "partner belajar" bagi peserta didik.(Zuriah \& Kautsar, n.d.-a)(Zuriah \& Kautsar, n.d.-b)

Hasil penelitian ini diharapkan dapat memberikan manfaat bagi para peneliti dalam bidang pendidikan, dosen dan mahasiswa. Hasil penelitian ini dapat memberikan informasi kepada para peneliti dalam bidang pendidikan tentang metode penelitian pengembangan . Bagi dosen dan mahasiswa, hasil penelitian pengembangan ini dapat menghasilkan bahan ajar media dan sumber belajar berbasis PPT For Android, yang dapat dijadikan salah satu sumber belajar dan rujukan inovasi pembelajaran dalam perkuliahan di prodi PPKn (Civic Hukum). Bagi praktisi pendidikan, hasil penelitian dapat digunakan sebagai rujukan untuk melakukan penelitian pengembangan.

\section{METODE}

Metode penelitian menggunakan model penelitian pengembangan ADDIE Model yang merupakan salah satu model desain pembelajaran sistematik. Romiszowski (Syracuse Univ., 1992) dan Tegeh (Tegeh et al., 2015b) mengemukakan bahwa pada tingkat desain materi pembelajaran dan pengembangan, sistematik sebagai aspek prosedural pendekatan sistem telah diwujudkan dalam banyak praktik metodologi untuk desain dan pengembangan teks, materi audiovisual dan materi pembelajaran berbasis androit dan komputer. Pemilihan model ini didasari atas pertimbangan bahwa model ini dikembangkan secara sistematis dan berpijak pada landasan teoritis desain pembelajaran. Model ini disusun secara terprogram dengan urutan-urutan kegiatan yang sistematis dalam upaya pemecahan masalah belajar yang berkaitan dengan sumber belajar yang sesuai dengan kebutuhan dan karakteristik pembelajar (Khadimally, 2015)(Lidinillah, 2011). Model ini terdiri atas lima langkah, yaitu: (1) analisis (analyze), (2) perancangan (design), (3) pengembangan (development), (4) implementasi (implementation) dan (5) evaluasi (evaluation). Secara visual tahapan ADDIE Model dapat dilihat pada gambar 1.1 berikut. 


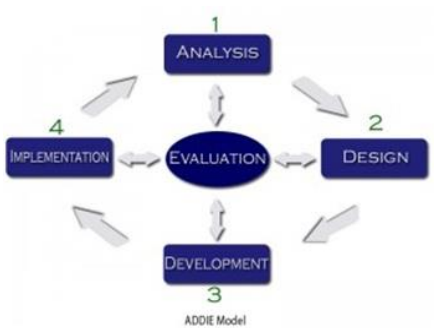

Gambar 1: Tahapan Model ADDIE (Tegeh et al., 2015b)(Tegeh et al., 2014)

\section{HASIL DAN PEMBAHASAN}

Sebelum menguraikan langkahlangkah pengembangan bahan Ajar dan media pembelajaran PPKn Berbasis Android dengan ADDIE Model, berikut dipaparkan kondisi kegiatan pembelajaran perkuliahan media dan sumber belajar PPKn sebelum diterapkannya pengembangan media pembelajaran berbasis android. Kondisi kegiatan belajar dan mengajar perkuliahan media sumber belajar PPKn sebelum adanya penerapan pengembangan media pembelajaran berbasis android di ruang kelas, mahasiswa ketika matakuliah media dan sumber belajar PPKn jam perkuliahannya sore hari yaitu jam 15.0017.30 wib. Ketika matakuliah media dan sumber belajar PPKn ditaruh pada saat jam pelajaran siang dan sore hari siswa kebanyakan mengantuk, tidak konsentrasi serta kurang semangat. Hal ini sebagaimana yang disampaikan dosen pembina mata kuliah Media Sumber Belajar PPKn sebagai berikut:

"Mahasiswa kalau jam pagi masih semangat tetapi ketika memasuki jam siang-sore hari semangatmya mulai turun, pada saat jam siang masingmasing mahasiswa mulai ada yang mengantuk, ramai sendiri, kurang semangat dalam belajarnya". (R/DP/29/10/2018)

Strategi yang biasa dilakukan dosen pembina matakuliah Media Sumber Belajar PPKn di Prodi PPKn / Civic Hukum UMM, untuk mengatasi hal tersebut adalah dengan melakukan kegiatan yang bisa merangsang semangat siswa dalam proses pembelajaran. Berikut adalah ringkasan hasil wawancara yang dilakukan peneliti dengan Dosen PPKn:

"Untukmengatasimahasiswayang mengantuk dan tidak semangat dalam proses pembelajaran, saya biasanya mengajak mahasiswa untuk melakukan gerakan-gerakan ringan supaya tidak mengantuk, tapi kalau tidak efektif biasanya akan saya suruh mengerjakan atau memberikan video menarik kepada mahasiswa.". (R/DP/27/10/2018).

Media pembelajaran yang biasanya digunakan Dosen PKn di kelas media dan sumber belajar adalah media konvensional dengan media pembelajaran menggunakan mediaPPT biasa(tradisional) di powerpoint yang berwarna-warni yang ditambahkan beberapa animasi dan film dari You Tube. Namun demikian, sayangnya, penggunaan media pembelajaran ini tidak begitu efektif dalam meningkatkan semangat mahasiswa dalam proses pembelajaran atau perkuliahan, hal ini diungkapkan oleh Dosen Pembina matakuliah Pengembangan Media dan Sumber belajar PKn, berikut ringkasan wawancaranya:

\section{"Penggunaan media pembelajaran ini kurang optimal, dikarenakan metode kurang menarik ". (R/ $\mathrm{DP} / 27032018$ ).}

Perkembangan media pembelajaran berbasis IT di Prodi PPKn sudah pernah dilakukan, namun kurang begitu optimal dikarenakan ada mahasiswa yang menyalahgunakan fasilitas IT untuk kegiatan-kegiatan negatif, sehingga akhirnya belum bisa memfasilitasi untuk adanya pengembangan media berbasis IT kalau menggunakan HP android, karena dikhawatirkan disalahgunakan. Jadi, untuk penggunaan android dalam pembelajaran 
di prodi PPKn-FKIP UMM diperbolehkan, namun perlu pendampingan dari pihak dosen atau orang yang paham IT dalam penggunaannya agar tidak disalahgunakan.

Pengembangan produk media pembelajaran berbasis Android dengan menggunakan "BENEKO EducApp" ini menggunakan jenis pengembangan metode ADDIE. Pengembangan ADDIE terdiri atas 5 fase yang saling terkait, yaitu Analyze, Design, Develop, Implement, dan Evaluate (Tegeh, dkk, 2014). Pelaksanaan pengembangan media pembelajaran dapat dirinci, sebagai berikut:

a. Tahapan Analyze

Pada model ADDIE, tahapan yang pertama kali adalah Analisis (Analyze). Tahapan ini merupakan tahap observasi, penemuan masalah, dan analisis permasalahan. Pada tahap ini penulis menganalisis permasalahan berdasarkan hasil observasi dan wawancara di kampus atau prodi PPKn.

Observasi peneliti lakukan melalui dua cara, yaitu pengamatan langsung dan wawancara kepada peserta didik dan pengajar terkait kondisi pembelajaran dan kebutuhan media pembelajaran. Dari hasil wawancara, peneliti menemukan permasalahan yaitu kurangnya minat belajar mahasiswa pada matakuliah PPKn dan pengembangan media dan sumber belajar PPKn yang berpengaruh pada hasil belajar mereka. Sehingga permasalahan yang muncul adalah bagaimana cara mengembangkan media belajar bagi peserta didik/mahasiswa agar meningkatkan minat belajar mereka.

b. Tahapan Design

Tahapan selanjutnya adalah design. Tahapan ini merupakan tahap penggagasan ide untuk menjawab permasalahan yang muncul. Ide yang digagas peneliti bersumber dari hasil observasi dan kajian literatur. Setelah diketahui bahwa permasalahan yang muncul adalah bagaimana cara mengembangkan media belajar yang dapat meningkatkan minat belajar peserta didik, maka peneliti memilih menggunakan aplikasi android sebagai medianya. Hal ini didorong oleh fenomena tuntutan pembelajaran abad 21 dan sebagian besar mahasiswa sudah sangat aktif dalam penggunaan gadget. Sehingga diharapkan apabila media pembelajaran yang dibuat berbasis android, peserta didik atau mahasiswa dapat lebih semangat dan mudah dalam mengaksesnya. Selain itu, diharapkan pula melalui media ini dapat meningkatkan penggunaan android kearah positif sehingga tidak disalahgunakan oleh peserta didik atau mahasiswa. Di dalam aplikasi yang dikembangkan, peneliti memiliki ide untuk ditambahkan fitur video, buku materi, game, kuis, serta media chatting dalam grup agar pengajar atau dosen dapat lebih mudah mengakses kebutuhan peserta didik/mahasiswa. Berangkat dari ide di atas, maka lahirlah ide membuat media pembelajaran PPKn berbasis Android melalui aplikasi "BENEKO EducApp" yang telah dihasilkan mahasiswa PPKn (Mohammad Nauval Al Kautsar) yang sekaligus sebagai tim dan kordinator lapangan penelitian ini.

c. Tahapan Develop

1) Membuat produk media pembelajaran berupa Aplikasi android

Setelah ide untuk menjawab permasalahan telah muncul, maka yang selanjutnya dilakukan adalah membuat dan mengembangkan aplikasi media pembelajaran PPKn berbasis Android dengan model "BENEKO EducApp" ini. Dikarenakan peneliti dan rekan-rekan mahasiswa tidak ada yang memiliki keterampilan akademik dibidang IT, maka peneliti bersama tim kordinator lapangan berusaha mengembangkan media android yang sederhana dan mampu dibuat dengan cukup mudah. Model yang dikembangkan berupa "BENEKO EducApp" ini dikembangkan melalui media Microsoft Power Point. Didalamnya terdapat 7 tahapan 
pembuatan sebagai berikut: pertama, menyiapkan video terkait pembelajaran. Video yang digunakan penulis cari di www.youtube.com yang sekiranya korelatif dengan materi pembelajaran. Kemudian video tersebut nanti dimasukkan ke slide power point yang akan dibuat. Menyiapkan buku materi pelajaran. Buku materi pelajaran dikembangkan sendiri dengan menggunakan aplikasi Book 3D di aplikasi ISpring. Sebelumnya penulis telah membuat buku materi terlebih dahulu dengan menggunakan berbagai literatur dan buku materi lainnya yang dapat lebih mudah dipahami peserta didik. Menyiapkan game. Game yang dikembangkan juga merupakan game interaktif sederhana yang dibuat menggunakan slide Power Point.

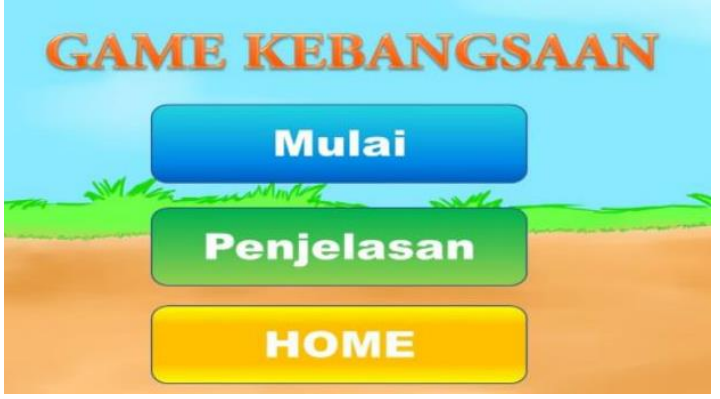

Gambar 2: Halaman awal game

Kedua, menyiapkan kuis. Kuis yang dibuat menggunakan aplikasi ISpring yang terkait dengan Microsoft Power Point.
Dengan menggunakan aplikasi ini, peserta didik dapat menjawab pertanyaan pilihan ganda dan langsung dapat melihat hasilnya.

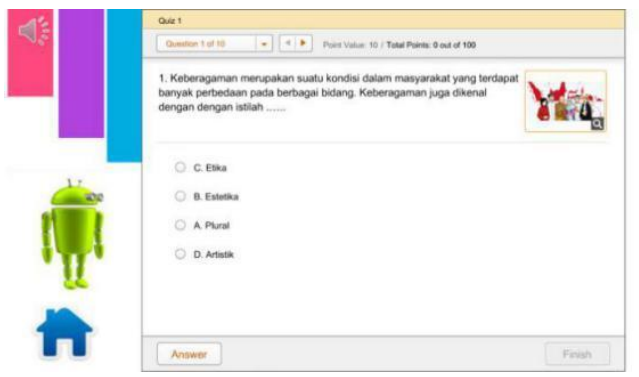

Gambar 3: Halaman kuis

Ketiga, menyiapkan media chatting. Media chatting yang dikembangkan adalah berbasis web blog, dimana pengembang harus mempunyai akun di chatango.com. Dalam media Chatting ini, peserta didik juga dapat membuat grup kelasnya masingmasing. Menyiapkan dan menjadikan keseluruhan persiapan dalam media Power Point. Setelah semua persiapan telah dilakukan, maka keseluruhannya disatukan dalam Power Point. Dapat dimasukkan langsung atau menggunakan aksi hyperlink.

Keempat, mengkonversi media Power Point menjadi aplikasi android. Terakhir adalah mengkonversi media Power Point menjadi aplikasi android dengan program Java 1.5 dan Andaired. Hasil akhirnya, media power point tersebut akan memiliki ekstensi .apk.

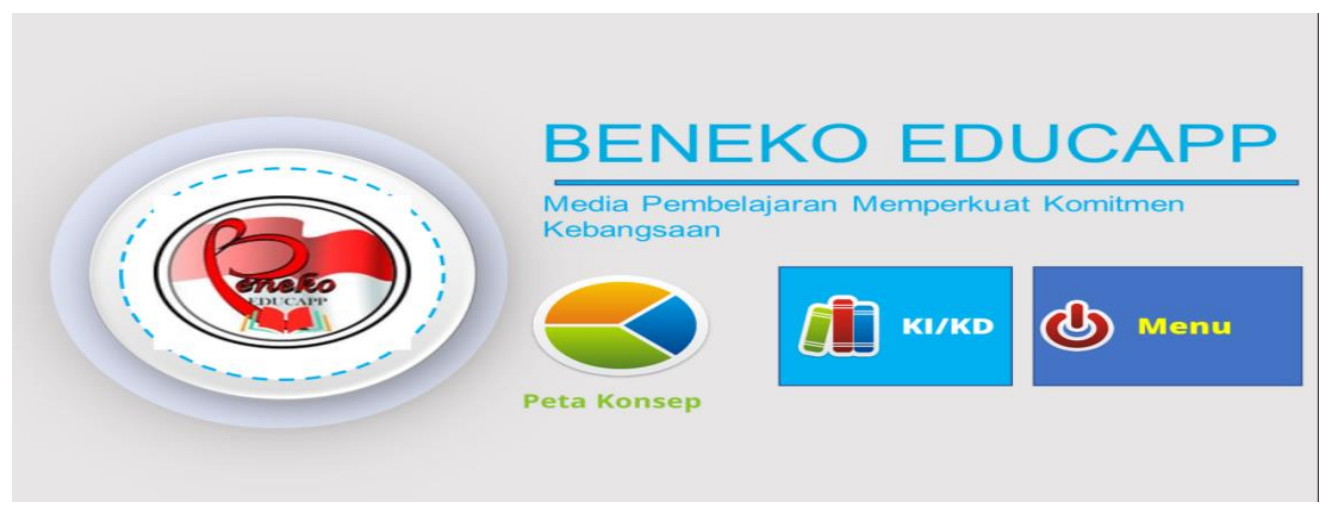

Gambar 4: Halaman awal aplikasi BENEKO educapp 


\section{d. Tahapan Implement}

Pada tahap implementasi ini, hasil pengembangan PPT for Android diterapkan dalam pembelajaran atau perkuliahan media sumber belajar PPKn, untuk mengetahui pengaruhnya terhadap kualitas pembelajaran/ perkuliahan yang meliputi aspek keefektifan, kemenarikan dan efisiensi pembelajarannya. Tahap implementasi ini akan dilakukan secara lebih intens nanti pada tahun ke dua (2019) yang akan mengkaji lebih jauh hasil validasi pengembangan bahan ajar dan media pembelajaran PPKn (PPT) berbasis Android dengan ADDIE Model. Serta mengkaji dan mendeskripsikan implementasi produk pengembangan bahan ajar dan media pembelajaran PPKn (PPT) berbasis Android di jurusan PPKnFKIP UMM beserta keunggulan dan kelemahannya.

\section{Tahap Evaluate}

Adalah tahap terakhir, yang dilakukan melalui evaluasi (evaluation) yang meliputi evaluasi formatif dan evaluasi sumatif. Evaluasi formatif dilakukan untuk mengumpulkan data pada setiap tahapan yang digunakan untuk penyempurnaan dan evaluasi sumatif dilakukan pada akhir program untuk mengetahui pengaruhnya terhadap hasil belajar peserta didik atau mahasiswa yang menempuh matakuliah media dan sumber belajar dan kualitas pembelajaran secara luas. Dalam penelitian ini hanya dilakukan pada tahap evaluasi formatif, karena berhubungan dengan tahapan penelitian pengembangan untuk memperbaiki produk pengembangan yang dihasilkan dan keterbatasan waktu penelitian.

Draft Produk Pengembangan Bahan Ajar dan Media Pembelajaran PPKn (PPT) berbasis Android di Jurusan PPKn-FKIP UMM.

Draft Produk Pengembangan Bahan Ajar dan Media Pembelajaran PPKn (PPT) berbasis Android di Jurusan PPKn-FKIP UMM dilakukan dengan tahapan sebagai berikut.
A. Membuat File Microsoft Power Point

1. Bukalah Microsoft Power Point. Pilih bagian "Design" dan Pilih "Page Setup".

2. Pilih layout "On-Screen Show (16:9)". Klik OK Tampilan Layar sudah berganti sesuai ukuran device Android.

3. Buatlah sebuah file powerpoint seperti biasanya namun jangan lupa buatlah sebuah tombol navigasi disetiap SLIDEnya.

B. Membuat Button

1. Pilih Tab "Insert" dan Pilih "Shapes".

2. Pilih bagian "Action Buttons: Custom".

3. Drag dan Drop ukuran Tombolnya. Untuk mengganti gambarnya, klik kanan dan pilih "Format Picture"

4. Browse file yang diinginkan dan klik "Close".

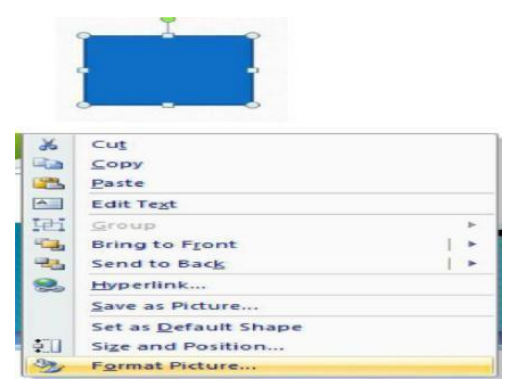

5. Bisa dilihat pada gambar cara membuat Judul Buku, Cover Depan dan belakang, warna dan model cover buku bisa diatur, cermati pada gambar di atas.

6. Jika sudah dianggap sip dan mantap lah untuk penentuan itu sekarang lihat gambar berikut, format jpg yang sudah ditata tadi kita perlukan disini

7. Klik ikon yang kami tunjukkan pada gambar, masukkan file jpg yang sudah ditata untuk tatanan buku yang dikehendaki. jadi satu halaman, untuk menambahkan halaman.

8. Tambahkan sesuai urutan yang diinginkan atau dikonsepkan sebelumya.

9. Klik Publish jika sudah selesai tunggu sebentar saat proses 
penyimpanan karena file hasil penyimpanan berformat swf kawankawan sudah tahu bahwa flash plyer atau aplikasi lain yang mendukung untuk memainkan ekstensi swf ini bisa berjalan pada laptop/komputernya.

G. Cara membuat chatting berbasis web blog

1) Daftar akun terlebih dahulu di.. http://chatango.com/ Klik Login terlebih dahulu di pojok atas layar home page, kemudian sign up, dan isikan formulir daftarnya. Setelah formulir di isi tinggal klik Sign Up.

2) Kemudia akan lanjut ke Step 2 dan 3. step 2 itu download apps untuk chat fersi desktop. lewati bisa tidak ingin mendowload. lanjut ke step 3 untuk pengisaian foto profil dan yg lainnya.

3) Dengan ini kamu sudah punya akun Chatango, dan bisa di gunakan chating. untuk memasang pada web / blog kamu harus buat grup terlebih dahulu. Nanti akan ada pilihan tampilan Grup. pilih saja yang box. kemudian isi nama grup dan yang lainnya jangan ada yang tertinggal. Kemudian klik "Create Grup" dan copy kodenya. letakan pada tempat yg kmu mau.

4) Jika kamu mau tampilannya pengin seperti pada blog ini kamu klik link share pada kode setelah klik "Create Grup" tadi. dan copy kode'nya kemudian paste pada tempat yang kamu mau.

H. Cara Mengconvert PPT ke Android

1. Install Program "Java 1.5.exe" seperti biasa
2. Buatlah sebuah folder baru dengan nama "android" di drive C atau D komputer. Lalu Copy file hasil publish "Power Point, Andaired dan Air SDK" serta FILE POWERPOINT yang sudah anda buat ke dalamsatu folder "android".

3. Masing-masing file ZIP, Klik Kanan dan "Extract to". Maka isi ZIP akan terekstrak dalam folder.

4. Buka folder "Andaired". Dan buka file "andaired.exe"

5. Pilih "Configuration".

6. Pilih "Aplication XML".

7. Klik "Generate Application Descriptor". Simpan hasilnya di folder Power Point.

8. Membuat Icon: Carilah Icon Gambar PNG (di CD). Klik "Create".

9. Sekarang tinggal membuat aplikasi andoidnya yaitu dengan cara klik"Build APK".

10. Buka Application Descriptor XML. Carilah file "application.xml". lakukan "Check".

11. Pilih Lokasi "APK Output File" (folder powerpoint).

12. Developer Certificate Password disi dengan "multidukasi".

13. Pilih "Add File" dan tambahkan file "presentation.xml" (di folder powerpoint).

14. Pilih "add Folder" dan tambahkan folder "data" (di folder powerpoint).

15. Klik "Build APK". dan tunggulah sampai muncul tulisan "test". Akhirnya aplikasi Android dari Powerpoint berhasil dibuat. 

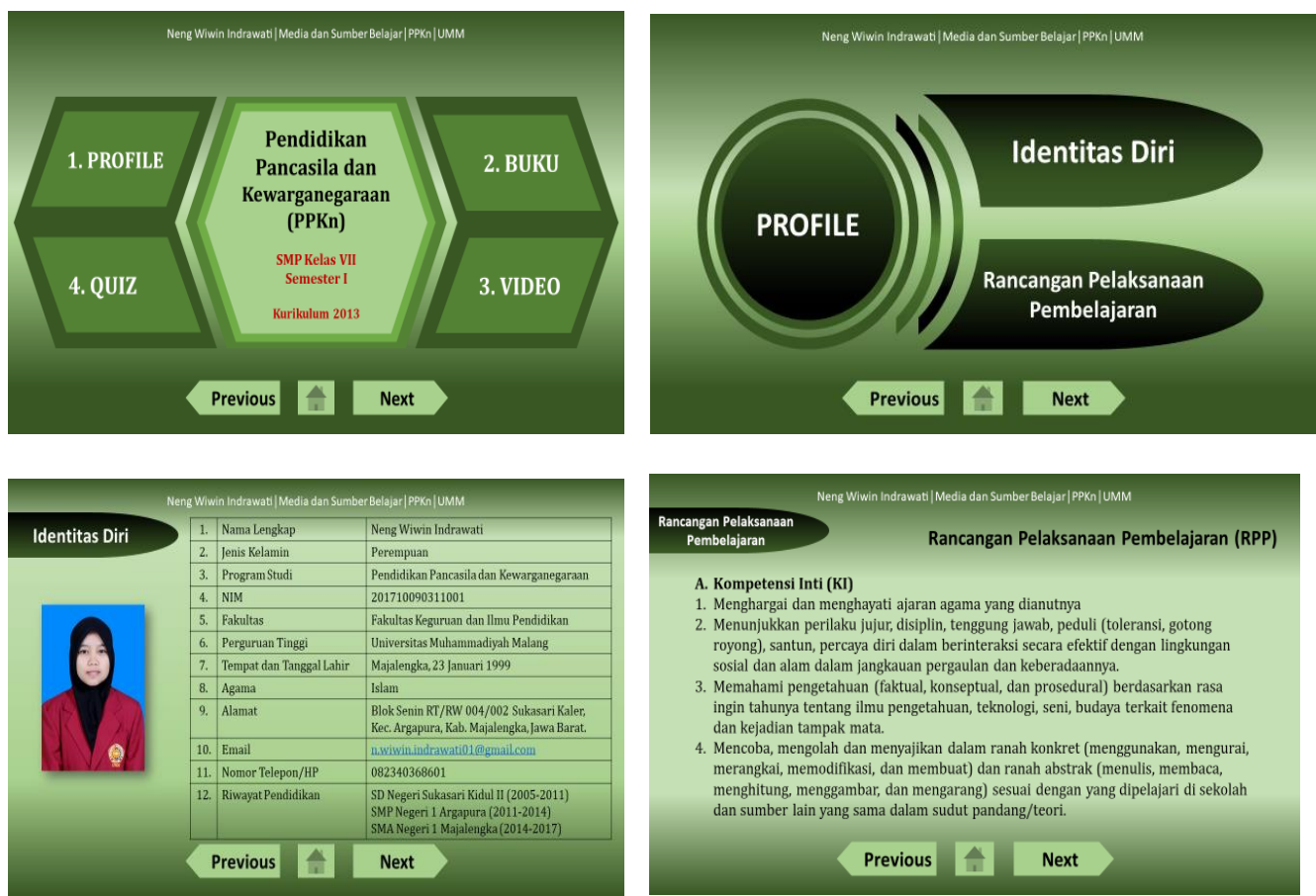

Gambar 5: Contoh PPT Produk Mahasiswa

\section{SIMPULAN}

Penelitian berbasis produk ini, merupakan sebuah Best Practice model penelitian pengembangan yang menggunakan model ADDIE (analisis, design, development, implementation and evaluation). Produk yang dihasilkan adalah media pembelajaran berbasis aplikasi android dalam matakuliah Pengembangan Media dan Sumber Belajar di jurusan PPKn-FKIP UMM. Salah satu modelnya adalah media BENEKO Educapp. Pengembangan media dikembangkan melalui lima tahapan (analisis, design, development, implementation and evaluation). Komponen media pembelajaran yang dikembangkan meliputi fitur video pembelajaran yang digunakan sebagai media pembelajaran PPKn, fitur buku digital untuk membantu siswa memahami materi, fitur quis untuk latihan dan evaluasi terkait pemahaman atas materi yang telah di sampaikan, fitur game untuk sarana refreshing siswa ketika jenuh dalam belajar, terakhir fitur chat room untuk sarana sharing antar guru dan siswa ketika susah memahami materi yang ada. Media di desain dengan menggunakan power point kemudian di convert ke aplikasi android menggunakan aplikasi andraired, desain aplikasi android menarik sesuai karakter peserta didik.

\section{DAFTAR PUSTAKA}

Andrews, D. H., \& Goodson, L. A. (1980). A comparative analysis of models of instructional design. Journal of Instructional Development. https:// doi.org/10.1007/BF02904348

Arham, U. U., \& Dwiningsih, K. (2016). Keefektifan Multimedia Interaktif Berbasis Blended Learning Untuk Meningkatkan Hasil Belajar Siswa. Jurnal Kwangsan, 4(2), 111. https:// doi.org/10.31800/jtp.kw.v4n2.p111$-118$

Budiyasa, I. M., Santyasa, I. W., \& Warpala, I. W. S. (2013). Pengembangan Bahan Ajar Dan Assessment Alternatif Online Mata Pelajaran Ipa Tingkat Smp Kelas Delapan Dengan Model Dick And Carey I. E-Journal Program Pascasarjana Universitas Pendidikan Ganesha.

Butzin, S. M. 2005. J. classroom in an, \& age 
of accountability: The project child recipe for success. Bloomington, I. P. D. K. I. (n.d.). No Title.

Degeng, I. N. S., \& Darmawan, I. P. A. (2017). Peningkatan Profesionalisme Pendidik Melalui Penelitian Dan Penulisan Karya Ilmiah. In Seminar Nasional Pendidikan Agama Kristen dan call for papers.

Degeng, M. D. K., Setyosari, P., Degeng, I. N. S., \& Kuswandi, D. (2017). Pengaruh Learning Control dalam Pembelajaran Menggunakan Media Web terhadap Hasil Belajar Pengetahuan Prosedural. Jurnal Pendidikan Dan Pembelajaran (JPP).

Egerton, M. (2002). Higher Education and Civic Engagement. The British Journal ofSociology, 53(4), 603-620.https://doi. org/10.1080/0007131022000021506

Farisi, M. I. (2011). Kompetensi Guru dalam Mewujudkan Pendidikan Berkarakter dan berbasis Budaya. Jurnal Teknologi Pendidikan, 11(1)(ISSN 0854-7149), 23-33. Retrieved from http://jm.tp. ac.id/view/1331224689/mohammadimam-farisi/kompetensi-guru-dalammewujudkan-pendidikan-berkarakterdan-berbudaya

Herawati, O. D. P., Siroj, R., \& Basir, H. M. D. (2010). Pengaruh Pembelajaran Problem Posing Terhadap Kemampuan Pemahaman Konsep Matematika Siswa Kelas Xi Ipa Sma Negeri 6Palembangects after removal of large jaw cysts-the two cases report. Jurnal Pendidikan Matematika Volume 4. NO.1 JUNI 2010. https://doi.org/10.2298/VSP1504368M

Khadimally, S. (2015). Designing effective curricula with an interactive collaborative curriculum design tool (CCDT). Turkish Online Journal of Educational Technology, 2015(3), 163-194.

Kowi, R., \& Widyanigsih, T. W. (2018). Indonesian Learning Culture Based On Android. International Journal of New Media Technology. https:// doi.org/10.31937/ijnmt.v4i1.532
Kurniawati, L., Akbar, R. O., \& Misri, A. (2015). Pengaruh Penerapan Metode Pembelajaran Praktikum Terhadap Keterampilan Berpikir Kritis Matematika Siswa Kelas VIII SMP NEGERI 3 Sumber Kabupaten Cirebon. Eduma.

Lidinillah, D. A. M. (2011). Educational Design Research: a Theoretical Framework for Action. Educational Design Research.

Manullang, B. (2013). Grand Desain Pendidikan Karakter Generasi Emas 2045. Jurnal Pendidikan Karakter, (1), 1-14. Retrieved from http:// journal.uny.ac.id/index.php/jpka/ article/view/1283

Miarso, Y. (2007). Tekologi yang Berwajah Humanis. Jurnal Pendidikan Penabur. Midun,H.,\&Ulfa,S.(2017). InovasiMetodeDan Penilaian Pembelajaran Pada Pendidikan Karakter Di Era Digital. Seminar Nasional Teknologi Pembelajaran Dan Pendidikan Dasar 2017.

Mullins, K. (2014). Good IDEA: Instructional Design Model for Integrating Information Literacy. Journal of Academic Librarianship. https://doi.org/10.1016/j. acalib.2014.04.012

Oey-Gardiner, M., Rahayu, S. I., Abdullah, M. A., Effendi, S., Darma, Y., Dartanto, T., \& Aruan, C. D. D. P. A.-1. pdfaniel. D. (2017). ERA DISRUPSI: Peluang dan Tantangan Pendidikan Tinggi Indonesia. Retrieved from https://www. aipi.or.id/index.php?pg=detilpublikasi \&pid=67\&type $=2$ \#reserach-tool-tab

Purbasari, R. julia, Kahfi, M. S., \& Yunus, M. (2013a). Pengembangan Aplikasi Android Sebagai Media Pembelajaran Matematika Pada Materi Dimensi Tiga Untuk Siswa SMA Kelas X. Jurnal Online Universitas Negeri Malang.

Purbasari, R. julia, Kahfi, M. S., \& Yunus, M. (2013b). Pengembangan Aplikasi 
Android SebagaiMedia Pembelajaran Matematika Pada Materi Dimensi Tiga Untuk Siswa SMA Kelas X. Jurnal Online Universitas Negeri Malang, 1-11. Retrieved from http:// lib.unnes.ac.id/3749/

Richey, R. C., \& Klein, J. D. (2014). Design and development research. In Handbook of Research on Educational Communications and Technology: Fourth Edition. https://doi. org/10.1007/978-1-4614-3185-5_12

Richey, R. C., Klein, J. D., \& Nelson, W. a. (2004). Developmental research: Studies of instructional deisgn and development. Handbook of Research for Educational Communications and Technology. https://doi.org/10.1007/9781-4614-3185-5_12

Ronald,A.(1987). Pemilihan dan Pengembangan Media Untuk Pembelajaran. Tim Terjemah, Yusuf Miarso, Dkk, Jakarta: PT Raja Grafindo Persada.

Saekhow, J. (2015). Steps of Cooperative Learning on Social Networking by Integrating Instructional Design based on Constructivist Approach. Procedia - Social and Behavioral Sciences. https://doi.org/10.1016/j. sbspro.2015.07.230

Sari, M. (2016). Blended learning, model pembelajaran abad ke-21 di perguruan tinggi. Ta'dib, 17(2), 126-136.

Schott, F., \& Seel, N. M. (2015). Instructional Design. In International Encyclopedia of the Social \& Behavioral Sciences: Second Edition. https://doi.org/10.1016/B978-0-08097086-8.92032-4

Setyosari, A. S. I. W. A. I. N. S. D. P. (2016). The Effects of Direct and Indirect Error CorrectionFeedback and Students? Attitudes on The Quality of Junior High School Students? Paragraph Writing. International Journal of Science and Research (IJSR).
Setyosari, P. (2009). Pemanfaatan Media. Malang: Universitas Negeri Malang. Social Engineering Collaboration Of Education Character And Multicultural Education: Praxis Educational Foundation In Sultan Iskandar Young. (2016). Jurnal Dimensi Pendidikan Dan Pembelajaran, 4(2), 186-193. Retrieved from http://psycnet. apa.org/psycinfo/1996-97171-000

Supriyo, S., Degeng, I. N. S., Widiati, U., \& Ardhana, I. W. (2017). The Effect of Practice Generalization Reinforcement (PGR) Instruction Strategy Vs Direct Instruction and Prior Knowledge on Learning Outcome of English Grammar in Junior High School. IOSR Journal of Research \& Method in Education (IOSRJRME). https://doi. org/10.9790/7388-070202100106

Syracuse Univ., N. Y. S. of E. (1992). Instructional Developments. $A$ Journal of the School of Education at Syracuse University, 1990-1992. Instructional Developments.

Tegeh, I. M., Jampel, I. N., \& Pudjawan, K. (2014). Model penelitian pengembangan. Yogyakarta: Graha Ilmu.

Tegeh, I. M., Jampel, I. N., \& Pudjawan, K. (2015a). Pengembangan Buku Ajar Model Penelitian Analyze Implement Evaluate Design Develop. Seminar Nasional Riset Inovatif.

Tegeh, I. M., Jampel, I. N., \& Pudjawan, K. (2015b). Pengembangan Buku Ajar Model Penelitian Pengembangan Dengan Model Addie. Seminar Nasional Riset Inovatif IV.

Zuriah, N., \& Kautsar, N. M. (n.d.-a). Development of PPKn Learning Media Based on Android.

Zuriah, N., \& Kautsar, N. M. (n.d.-b). Development of PPKn Learning Media Based on Android. In 6th International Conference on Community Development (ICCD 2019). Atlantis Press. 